\title{
The impact of nutritional supplement use on the prevalence of inadequate micronutrient intakes in 18-64 year old Irish adults
}

\author{
F. Browne, J. Walton and A. Flynn \\ School of Food and Nutritional Sciences, University College Cork, Republic of Ireland
}

The objective of this study was to investigate the influence of nutritional supplement use on the prevalence of inadequate micronutrient intakes in Irish adults aged 18-64 years. Analysis was based on the National Adult Nutrition Survey (NANS) (2008-2010), which was carried out to establish a database of habitual food and drink consumption in a representative sample of 18-64 year old Irish adults $(n=1274)$. A 4 day semi-weighed food record was used to collect food intake data and analysis was carried out using WISP ${ }^{\odot}$ (Tinuviel Software, Anglesey, UK), which is based on McCance and Widdowson's The Composition of Foods, Sixth Edition ${ }^{(1)}$ and the Irish Food Composition Database ${ }^{(2)}$. The database was updated to include all nutritional supplements recorded by participants in the food diary. A supplement user was defined as a respondent who consumed a nutrient containing supplement over the 4-day recording period. For selected micronutrients, the percentage of individuals with intakes less than the UK estimated average requirement (EAR) ${ }^{(3)}$ are reported. For vitamin D, the IOM EAR ${ }^{(4)}$ of $10 \mu \mathrm{g}$ and cut-offs of $5 \mu \mathrm{g}$ and $1 \mu \mathrm{g}$ were used to assess adequacy. Under-reporters were excluded from the analysis. Minimum energy intakes cut off points ${ }^{(5)}$ (Goldberg et al., 1991), calculated as multiples of BMR (Tanita BC 420MA Body Composition Analyser) were used to identify under-reporters.

\begin{tabular}{|c|c|c|c|c|c|c|c|}
\hline \multirow[b]{2}{*}{ Micronutrient } & \multirow[b]{2}{*}{ EAR } & \multicolumn{2}{|c|}{ Supplement Users (All Sources) } & \multicolumn{2}{|c|}{ Supplement Users (Food Sources) } & \multicolumn{2}{|c|}{ Non-Users (Food Sources) } \\
\hline & & Males $(n=105)$ & Females $(n=152)$ & Males $(n=105)$ & Females $(n=152)$ & Males $(n=343)$ & Females $(n=289)$ \\
\hline & & & & & EAR & & \\
\hline Calcium & $\begin{array}{l}750 \mathrm{mg} \text { (males, 18y) } \\
625 \mathrm{mg}(\text { females, } 18 \mathrm{y}) \\
525 \mathrm{mg}(19 \mathrm{y}+)\end{array}$ & 1 & 9 & 2 & 11 & 4 & 10 \\
\hline Iron & $\begin{array}{l}8.7 \mathrm{mg} \text { (males, } 18 \mathrm{y}) \\
11.4 \mathrm{mg}(\text { females, } 18-50 \mathrm{y}) \\
6.7 \mathrm{mg}(\text { males, } 19 \mathrm{y}+) \\
6.7 \mathrm{mg} \text { (females, } 50 \mathrm{y}+\text { ) }\end{array}$ & 0 & 25 & 0 & 40 & 2 & 49 \\
\hline Magnesium & $\begin{array}{l}250 \mathrm{mg} \text { (males) } \\
250 \mathrm{mg} \text { (females, } 18 \mathrm{y}) \\
200 \mathrm{mg} \text { (females, } 19 \mathrm{y}+\text { ) }\end{array}$ & 6 & 11 & 8 & 15 & 13 & 19 \\
\hline Zinc & $\begin{array}{l}7.3 \mathrm{mg} \text { (males, } 18 \mathrm{y}+) \\
5.5 \mathrm{mg} \text { (females, } 18 \mathrm{y}+\text { ) }\end{array}$ & 5 & 3 & 7 & 5 & 9 & 11 \\
\hline Vitamin A & $\begin{array}{l}500 \mu \mathrm{g} \text { (males, } 18 \mathrm{y}+\text { ) } \\
400 \mu \mathrm{g}(\text { females, } 18 \mathrm{y}+\text { ) }\end{array}$ & 7 & 6 & 14 & 10 & 21 & 14 \\
\hline Vitamin D & $\begin{array}{l}10 \mu \mathrm{g}(18 \mathrm{y}+) \\
5 \mu \mathrm{g}(18 \mathrm{y}+)\end{array}$ & $\begin{array}{r}71 \\
35 \\
15\end{array}$ & $\begin{array}{l}83 \\
57 \\
3\end{array}$ & $\begin{array}{r}97 \\
74 \\
2\end{array}$ & $\begin{array}{r}99 \\
86 \\
6\end{array}$ & $\begin{array}{r}98 \\
82 \\
8\end{array}$ & $\begin{array}{l}98 \\
87 \\
13\end{array}$ \\
\hline
\end{tabular}

Nutritional supplements reduced the $\%$ of users with inadequate intakes for iron (females only), vitamin A (males only) and vitamin D (both males and females) in 18-64 year old Irish adults. Users of nutritional supplements had a lower prevalence of inadequate intakes compared to non-users for iron (females only) and vitamins A and D.

This project was funded by the Irish Department of Agriculture, Food and the Marine under the Food for Health Research Initiative $2007-2012$.

1. Food Standards Agency (2002) McCance \& Widdowson's The Composition of Foods Sixth Edition including supplemental volumes. Cambridge: Royal Society of Chemistry.

2. Black LJ, Ireland J, Møller A, et al. (2011) J Food Comp Anal 24, 1017-23.

3. Department of Health UK (1991) Dietary Reference Values for Food Energy and Nutrients for the United Kingdom. Reports on Public Health and Social Subjects No. 41. London: H.M.S.O.

4. Institute of Medicine (2011) Dietary Reference Intakes for Calcium and Vitamin D. Washington, DC: The National Academies Press.

5. Goldberg GR, Black AE, Jebb SA et al. (1991) Eur J Clin Nutr 45(12), 569-81. 